\title{
A Horticultural Medium Established from the Rapid Removal of Phytotoxins from Winery Grape Marc
}

\author{
Kenneth J. Olejar *,+ ${ }^{*}$, Charlotte Vandermeer, Bruno Fedrizzi $₫$ and Paul A. Kilmartin $₫$ \\ School of Chemical Sciences, The University of Auckland, Private Bag 92019, Auckland, New Zealand; \\ cvan106@aucklanduni.ac.nz (C.V.); b.fedrizzi@auckland.ac.nz (B.F.); p.kilmartin@auckland.ac.nz (P.A.K.) \\ * Correspondence: Kenneth.OlejarJr@lincoln.ac.nz; Tel.: +64-3-423-0600 \\ † Currently address: Department of Wine, Food, and Molecular Bioscience, Lincoln University, P.O. Box 85084, \\ Lincoln, New Zealand.
}

Received: 13 June 2019; Accepted: 24 September 2019; Published: 2 October 2019

check for updates

\begin{abstract}
Grape (Vitis vinifera L.) marc has long been utilized as a compost feedstock. However, this process takes an extended period of time due to the phytotoxic chemical composition of the marc. Removal of these compounds presents an opportunity to utilize the grape marc as a growing medium. Following a water-based extraction procedure to remove polyphenolic compounds of interest, analysis of the depleted marc showed a decrease in the content of these compounds, and in nutrient and trace element levels. Carrot (Daucus carota L.) and corn (Zea mays L.) seedling emergence in the depleted marc and blends with compost were not adversely affected, demonstrating its effectiveness for growing plants at all ratios. A 50:50 blend of compost and depleted grape marc resulted in plant growth equivalent to the compost alone. This combined with the observed water holding capacity suggests that depleted grape marc, when blended with compost, can be a suitable alternative to peat or coconut coir for seedlings.
\end{abstract}

Keywords: circular economy; seedling emergence medium; soilless culture; sustainable agriculture; winery agro-waste; Vitis vinifera L.; carrot; corn

\section{Introduction}

Processing of food products results in large quantities of agricultural waste. In the wine industry, this waste takes several forms. However, the predominant sources are the grape (Vitis vinifera L.) skins, seeds, and extraneous materials following pressing operations, known as grape marc [1]. Grape marc can be utilized as feedstock for the production of grape spirits [1], compost [1-3], as feed for livestock $[1,4,5]$, or functionally enhanced through fermentation for nutraceuticals $[2,6]$. Utilization as livestock food can present nutritional problems in ruminants due to the high polyphenolic content of the grape marc [7,8], which also makes it unsuitable for immediate use as a soil additive on cultivated land [9] and can present similar issues as found in other soilless growing media [10]. Due to phytotoxicity and antimicrobial effects as a result of released tannins and polyphenols, an extended composting time is required for the grape marc and the woody grape vine wastes to become suitable for agricultural use [11,12]. Long composting times of greater than 5 months are required to compost grape pomace, which is dependent on the feedstock added, turning frequency, moisture, and temperature of the piles [13]. However, this is not without problems, as many phytotoxins (polyphenolic compounds, organic acids, and other bioactive molecules) and heavy metals are leached by rain from the marc and enter surrounding soils and water, having a negative impact on the environment [14]. Berry components of white grape cultivars contain varying amounts of phenolic compounds with $20 \%-55 \%$ of the total phenolics in the seed, which consists of flavan-3-ols. The skins contain $25 \%-60 \%$ of the phenolic content, which consists mainly of organic acids, phenolic acids, and flavonoids. The rachis contains 
about $20 \%$ of the total phenolic content $[15,16]$. The composition of phenolic compounds will be similar in red grape clusters with the main exception of anthocyanins found in the red grape skin $[17,18]$.

Phenolic compounds, known to be phytotoxic to plants, have found many uses due to their associated health benefits and uses in the food industry [6]. Methods of extraction typically involve one or more food approved organic solvents to maximize the extraction process [19-21]. The most common solvents utilized for solid-liquid extraction of polyphenols are methanol, ethanol, acetone, diethyl ether, and ethyl acetate [22]. Residues of these organic solvents, besides being possibly hazardous to human health, remain in the extract and depleted marc [22]. These solvents must be allowed to evaporate in order to utilize the depleted marc for composting, as several of the solvents are antimicrobial which can inhibit the composting process $[23,24]$. The volatilization process can generate the potential for greater environmental impact through leaching of solvents and their evaporation into the air [25]. As such, utilizing ecologically friendly extraction processes will enable a quicker utilization of the depleted marc.

In order to alleviate the problems associated with organic solvents, a water-based extraction process was utilized to remove polyphenols, which can subsequently be used in applications requiring the active phenolic and tannin compounds [26-28]. This resulted in a depleted marc that was studied for its potential as a horticultural medium and/or immediate application to cultivated land.

\section{Materials and Methods}

\subsection{Materials}

White grape marc from Sauvignon blanc wine production was obtained from Marlborough, New Zealand during the 2014 and 2015 harvests. The collection of marc occurred in late March for both vintages. The Sauvignon blanc grapes harvested at this time were between 20.5 and $22.5^{\circ} \mathrm{Bx}$. The yearly meteorological data for 2014 were: rainfall $510 \mathrm{~mm}$, max temperature $30.0^{\circ} \mathrm{C}$, min temperature $-2.3^{\circ} \mathrm{C}$, and growing degree days 1533; while for 2015 they were: rainfall $381 \mathrm{~mm}$, max temperature $30.8^{\circ} \mathrm{C}$, min temperature $-3.0^{\circ} \mathrm{C}$, and growing degree days 1460 [29]. The vines were managed by vertical shoot positioning and were mechanically harvested in March of both years. 'Xtra Tender F1 Hybrid' corn (Zea mays L. var. saccharata) and 'Manchester' table carrot (Daucus carota L.) seeds were obtained from AHM (Auckland, New Zealand), a distributor of gardening products in Australasia. Tui Essentials compost (Tui, Mount Maunganui, New Zealand) was obtained from the local market Mitre 10 (Auckland, New Zealand). The reagents for the 2,2-diphenyl-1-picrylhydrazyl (DPPH) assay consisted of DPPH (Sigma-Aldrich, St. Louis, MO, USA) and methanol (Scharlau, Sentmenat, Spain).

\subsection{Polyphenolic Compound Depletion}

Sauvignon blanc grape marc consisting of seeds, skins, and rachis was extracted using a modified procedure described by Olejar et al. [30]. Briefly, $5 \mathrm{~kg}$ of grape marc was mixed with $5.0 \mathrm{~L}$ of water and passed through an inline macerator, model ME 4100 (Inoxpa S.A.U., Banyoles, Spain), producing a particle size of less than 100 microns. The ground marc was extracted for $24 \mathrm{~h}$, then pressed using a $20 \mathrm{~L}$ hydraulic basket press, model Hydro 20 (Zambelli Enotech, Camisano, Italy), increasing the pressure to $2.0 \mathrm{psi}$ and holding until liquid flow had ceased. The press cake was broken and pressed a second time until liquid flow had ceased. The depleted marc was stored at $-4{ }^{\circ} \mathrm{C}$ until blending.

\subsection{Depleted Marc Properties}

Triplicate samples of the depleted marc were subjected to loss on ignition (LOI) testing to determine percent ash and percent organic carbon [31]. Briefly, the grape marc was dried at $100^{\circ} \mathrm{C}$ until a constant weight was achieved. The dried marc was weighed and placed into a previously dried and weighed ceramic crucible and heated to $375^{\circ} \mathrm{C}$ over $30 \mathrm{~min}$. After holding for $1 \mathrm{~h}$, the temperature was raised to $550{ }^{\circ} \mathrm{C}$ over $30 \mathrm{~min}$ and held for $4 \mathrm{~h}$. Samples were removed and cooled in a desiccator prior to 
weighing. The percentage ash and total organic carbon (TOC) were then calculated with Equations (1) and (2):

$$
\begin{aligned}
& \% \text { Ash }=\left[\frac{(P I-D S)}{D S}\right] \times 100 \\
& \text { TOC }=(100-\% A s h) \times 0.58
\end{aligned}
$$

where $D S$ is the dried sample weight, $P I$ is the sample weight post ignition, and 0.58 is the conversion factor for organic material to organic carbon [31].

The water holding capacity $(W H C)$ of the depleted marc was determined by modification of the method of Naeth et al. [32]. Buchner funnels were filled with dried marc prior to weighing and saturation in $70^{\circ} \mathrm{C}$ water for $24 \mathrm{~h}$. Samples were covered to prevent evaporation and kept at room temperature. The samples were returned to the Buchner funnels and excess water then allowed to drain for $24 \mathrm{~h}$ prior to reweighing and calculation of the water holding capacity. Water holding capacity was calculated as

$$
W H C=\left[\frac{(W M-D M)}{D M}\right] \times 100
$$

where $D M$ is the dry mass of the sample, and WM is the drained mass of the sample [32].

The depleted marc was subjected to the DPPH assay for antioxidant activity. The DPPH assay is a measure of the compounds present in a substance or solution that are able to scavenge the DPPH radical. In this context, it allows for the determination of phenolics and other bioactive compounds that remain in the depleted marc. The DPPH assay was run according to the method outlined by Olejar et al. [27] with the following modification. DPPH radical solution was made in $80 \%$ methanol for a final concentration of $127.5 \mu \mathrm{mol} \cdot \mathrm{L}^{-1}$. To $20 \mathrm{~mL}$ of the radical solution, $10.0 \mathrm{mg}$ of the depleted marc was added. The samples were protected from light and allowed to incubate at room temperature for $24 \mathrm{~h}$. The absorbance was measured at $515 \mathrm{~nm}$ using $80 \%$ methanol as a blank using a Shimadzu UV-1700 spectrophotometer (Shimadzu, Auckland, NZ). A DPPH standard curve was made by serial dilution of standards of concentrations at $127.5,63.8,31.9,15.9$, and $8.0 \mu \mathrm{mol} \cdot \mathrm{L}^{-1}$.

\subsection{Depleted Marc Compost Blend Properties}

The moisture content of all the marc blends was tested in triplicate. Briefly, air dried soil (10 g) was weighed and subsequently dried at $100{ }^{\circ} \mathrm{C}$ until a constant weight was achieved [33]. The samples were cooled in a desiccator and the moisture content was then calculated using the formula

$$
\% M C=\left[\frac{(A D-O D)}{O D}\right] \times 100
$$

where $M C$ is moisture content, $A D$ is the weight of the air dried sample, and $O D$ is the weight of the oven dried sample [33].

The $\mathrm{pH}$ was obtained on all growth media by weighing approximately $10 \mathrm{~g}$ into a beaker and adding an equal volume of water. This was mixed for $30 \mathrm{~min}$ prior to centrifugation at 10,000 rpm for 10 min (Sorvall, Thermo Fisher Scientific, Waltham, MA, USA). The $\mathrm{pH}$ was then determined on the liquid (Thermo Orion 420A, Thermo Fisher Scientific, Waltham, MA, USA).

Growth media were allowed to naturally compact prior to coring for bulk density and water penetration analysis. Bulk density was calculated as below (Equation (5)) following drying of the soil cores until a constant weight was obtained and utilizing the core volume.

$$
\text { Bulk Density }=\frac{\text { Oven dried core weight }}{\text { Core volume }}
$$

To air dried cores, 10 drops of deionized water were added. A stopwatch was used to time the complete absorption of the water. The time for penetration was used to determine the soil repellency via the table in Leelamanie et al. [34]. 
Nutrient profiling of raw grape marc, depleted grape marc, compost, and 50\% grape marc compost blend was undertaken at the commercial testing lab of RJ Hill Laboratories (Hamilton, New Zealand). The tests included: $\mathrm{pH}$, electrical conductivity, nitrate-N using 1:1.5 $(v / v)$ water extraction followed by salicylate colorimetry, ammonium-N using 1:1.5 $(v / v)$ water extraction followed by Berthelot colorimetry, phosphorus, potassium, sulfur, calcium, magnesium, and sodium using a 1:1.5 $(v / v)$ water extract followed by inductively coupled plasma optical emission spectrometry (ICP-OES); iron, manganese, zinc, copper, and boron using $2 \mathrm{mM}$ DPTA extraction followed by ICP-OES; and nitrogen drawdown index following Australian standard 3743-1989 followed by salicylate colorimetry for nitrate- $\mathrm{N}[35,36]$.

\subsection{Seedling Emergence Tests}

The depleted grape marc was mixed with compost at concentrations of $0 \%, 25 \%, 50 \%, 75 \%$, and $100 \% v / v$ depleted marc and placed into $13 \mathrm{~L}$ plastic buckets with dimensions $25 \mathrm{~cm}$ in height and $26 \mathrm{~cm}$ in diameter filled to $8 \mathrm{~L}$. Utilizing the Environmental Protection Agency (EPA) seedling emergence testing guidelines [37], ten carrot seeds per bucket were planted in duplicate and five corn seeds per bucket were planted in replicate $(n=4)$. Seeds were planted at a depth specified by the manufacturer-carrot at $1 \mathrm{~cm}$ depth and corn at $3 \mathrm{~cm}$ depth-and top watered to stimulate growth. The buckets were then placed into bins with water to ensure constant moisture content. Water was added to the bins as required to ensure that the necessary water was available to be drawn into the soil as needed. The air and soil temperatures, as well as sunlight, were monitored using a dataTaker DT800 (Thermo Fisher, Scoresby, Australia) with DeLogger 4 software (Rowville, Aus., v. 2, release 14). Rainfall was measured using a rain gauge positioned next to the growing plot. All containers received equal amounts of water to maintain moist conditions, soils were top watered as necessary based on observational dryness of the crust, and data readings were taken from a soil moisture meter (Spectrum Technologies, Aurora, IL, USA). Growth was monitored and Day 0 indicated 50\% emergence of the seeds planted in the control soil of $0 \%$ grape marc. Plant emergence was monitored and recorded over the length of the study. Percent emergence was calculated by dividing the total seedlings emerged by the total seeds planted. Additionally, percent viability was calculated from the number of seedlings emerged divided by the number of seedlings that remained alive at the end of the study period. The test time was 14 days, after which the plants were gently removed from the soil, washed to remove any adhering soils, and measured. The length of the shoot and root were recorded prior to their separation. The plant parts were then weighed prior to and after drying in a $100{ }^{\circ} \mathrm{C}$ oven until a constant weight was obtained.

\subsection{Statistical Methods}

Data was analyzed for significance utilizing JMP 13.0 for Mac (SAS Institute Inc., Cary, NC, USA). Data was subjected to one-way ANOVA with Tukey-Kramer honestly significant difference (HSD) post-hoc testing.

\section{Results and Discussion}

\subsection{Depleted Marc Characteristics}

The physical characteristics of the depleted grape marc were evaluated prior to combining with compost for the final growth blends. As such, the water holding capacity (WHC) was $61.1 \%$, percentage ash was $2.3 \%$, and DPPH radical scavenging was $0.020 \pm 0.003 \mathrm{~g}$ DPPH/g depleted marc. The ash percentage was expected as a result of the organic origin of the samples. These results are also in agreement with those in the literature for grape marc compost [31] and grape marc silage [7]. The WHC demonstrated the ability of the marc to retain water once saturated, as this aspect is important in minimizing runoff and erosion [38]. The DPPH capacity demonstrated that some bioactive compounds remained and could contribute to phytotoxicity. By comparison, this value was only $15 \%$, a fraction of the scavenging from a grape seed water extract, $0.13 \pm 0.04 \mathrm{~g} \mathrm{DPPH} / \mathrm{g}$ 
seed, obtained by Bucić-Kojić et al. [39]. The depleted marc scavenging demonstrated the significant reduction in bioactive compounds and the reduction in potential phytotoxic effects resulting from the depletion process.

\subsection{Depleted Marc Blends}

The attributes of the depleted marc blends are presented in Table 1. Compost was blended to achieve volume equivalent with depleted marc concentrations of $25 \%, 50 \%, 75 \%$, and $100 \%$, while $0 \%$ depleted marc ( $100 \%$ compost) served as a positive control. The $\mathrm{pH}$ values of the media decreased significantly versus the control as the marc concentration increased. However, even though the $\mathrm{pH}$ was within an acceptable range for plant growth, the $\mathrm{pH}$ decrease in the blended soils would be more conducive to plants requiring slightly acidic soils, as seen in the growth of carrots and corn in the present study. The studies of Gentili et al. [40] demonstrated that a sub-optimum pH was more conducive for increased growth in Ambrosia artemisiifolia L. The acidic nature of the grape marc, noting that the raw marc was measured at $\mathrm{pH}$ 4.0, which is equivalent to that observed by Gómez-Brandón et al. [11], may be linked to residual organic acids, and could present problems for growth of plants requiring neutral to basic soils. To grow plants favoring basic conditions, the $\mathrm{pH}$ of the marc could be adjusted through incorporation of compounds such as lime; in contrast, the acidic nature of the depleted marc could be utilized to adjust the $\mathrm{pH}$ of basic soils.

Table 1. Physical properties and $\mathrm{pH}$-values of depleted grape marc and compost blends. $(n=3$, except water penetration $n=5)$.

\begin{tabular}{ccccc}
\hline \% Marc Concentration & $\mathbf{p H}$ & Bulk Density $(\mathrm{g} / \mathrm{V})$ & Moisture Content (\%) & Water Penetration (sec) \\
\hline 0 & $7.02 \pm 0.06 \mathrm{a}^{\mathrm{z}}$ & $0.40 \pm 0.16 \mathrm{nd}$ & $91.3 \pm 0.0 \mathrm{a}$ & $3.8 \pm 2.5 \mathrm{a}$ \\
25 & $6.85 \pm 0.03 \mathrm{~b}$ & $0.42 \pm 0.02$ & $89.9 \pm 0.0 \mathrm{~b}$ & $2.5 \pm 1.3 \mathrm{a}$ \\
50 & $6.76 \pm 0.01 \mathrm{c}$ & $0.50 \pm 0.04$ & $85.0 \pm 0.0 \mathrm{~d}$ & $1.8 \pm 1.0 \mathrm{a}$ \\
75 & $6.42 \pm 0.01 \mathrm{~d}$ & $0.51 \pm 0.01$ & $87.6 \pm 0.0 \mathrm{c}$ & $4.0 \pm 2.6 \mathrm{a}$ \\
100 & $5.58 \pm 0.01 \mathrm{e}$ & $0.26 \pm 0.11$ & $79.7 \pm 0.0 \mathrm{e}$ & $48 \pm 37 \mathrm{~b}$
\end{tabular}

${ }^{\mathrm{z}}$ Different letters in each column signify the values are significantly different using one-way repeated measures using Tukey-Kramer honestly significant difference (HSD) $(p<0.05)$. nd indicates no significant difference among means.

The bulk densities of the blends were not significantly different, nor the time required for water to penetrate the blends, with the exception of depleted $100 \%$ marc. The bulk densities do not suggest compaction of the soils, but rather that they are loose [41]. The times required for water penetration suggest that the tested media were slightly water repellent [34]. It was further observed that the water penetration time was impacted by the size of the grape marc surface particles. Larger clods of marc required greater times for the moisture to penetrate, as shown in the $100 \%$ depleted marc, and may occur as a result of the surface drying characteristics observed and the lack of cracks allowing moisture to penetrate. This is supported by the study of Ahmad [42], where water penetration was influenced by the appearance and degree of cracks in the clods. This observation combined with the water repellency presents a possible use for the $100 \%$ depleted marc as a biodegradable seedling pot. The non-toxic and soil supplementing nature of a biodegradable pot made from depleted marc would allow for direct transfer to the planting bed and allow root growth to migrate through to the surrounding soil. Further testing is required to validate this application, as the pots must be able to withstand multiple water exposures and allow for root expansion to be effective for commercial retail use.

Although the depleted marc demonstrated an ability to hold water, this did not impact the moisture content of the depleted marc blends. As the depleted marc concentrations increased, the moisture content decreased by $12 \%$, as shown in Table 2. Moisture content, a measure of the water present, is influenced by not only gravitational drainage but also by evaporative forces. The depleted marc was observed to have greater surface drying, as noted in the water penetration studies. The cause for the increased evaporation could be linked to the particle size of the depleted marc, less than 100 microns. An et al. [43] found that soil surface characteristics and atmospheric conditions influenced 
the evaporation rate and overall moisture content of soils. The soil grain sizes in the study influenced the evaporation process [43].

Table 2. Seedling emergence data of carrot $(n=2)$ and corn plants $(n=4)$ in compost and depleted grape marc blends.

\begin{tabular}{|c|c|c|c|c|c|c|}
\hline \multirow{2}{*}{$\begin{array}{c}\% \text { Marc } \\
\text { Concentration }\end{array}$} & \multicolumn{6}{|c|}{ Carrot } \\
\hline & $\%$ Emergence & \% Viability & Root (cm) & Stalk (cm) & $\begin{array}{c}\operatorname{Root}^{\mathrm{z}} \\
\text { (mg/plant) }\end{array}$ & $\begin{array}{c}\text { Stalk } \\
\text { (mg/plant) }\end{array}$ \\
\hline 0 & $72.5 \pm 17.7$ nd $^{y}$ & $90.0 \pm 2.5 \mathrm{nd}$ & $58 \pm 17 b$ & $21 \pm 5 \mathrm{nd}$ & $0.91 \pm 0.01 \mathrm{ab}$ & $1.67 \pm 0.25 \mathrm{nd}$ \\
\hline 25 & $65.0 \pm 14.1$ & $96.7 \pm 4.7$ & $72 \pm 14 \mathrm{a}$ & $20 \pm 5$ & $0.98 \pm 0.07 \mathrm{ab}$ & $1.56 \pm 0.01$ \\
\hline 50 & $90.0 \pm 0.0$ & $88.9 \pm 0.0$ & $72 \pm 15 a$ & $21 \pm 3$ & $1.19 \pm 0.02 \mathrm{a}$ & $1.32 \pm 0.03$ \\
\hline 75 & $87.5 \pm 17.7$ & $91.7 \pm 2.4$ & $68 \pm 13 a b$ & $22 \pm 6$ & $1.25 \pm 0.11 \mathrm{a}$ & $1.51 \pm 0.28$ \\
\hline \multirow[t]{2}{*}{100} & $77.5 \pm 3.5$ & $90.2 \pm 5.0$ & $64 \pm 18 \mathrm{ab}$ & $22 \pm 3$ & $0.53 \pm 0.24 b$ & $1.38 \pm 0.16$ \\
\hline & \multicolumn{6}{|c|}{ Corn } \\
\hline $\begin{array}{c}\% \text { Marc } \\
\text { Concentration }\end{array}$ & \% Emergence & $\%$ Viability & Root (cm) & Stalk (cm) & $\begin{array}{c}\operatorname{Root}^{\mathrm{z}} \\
\text { (mg/plant) }\end{array}$ & $\begin{array}{c}\text { Stalk }^{z} \\
\text { (mg/plant) }\end{array}$ \\
\hline 0 & $75.0 \pm 25.2 \mathrm{nd}$ & $100 \pm 0$ nd & $30 \pm 6 a$ & $21 \pm 6 a$ & $155 \pm 23 \mathrm{ab}$ & $87.9 \pm 49.9$ nd \\
\hline 25 & $80.0 \pm 28.3$ & $100 \pm 0$ & $17 \pm 3 b$ & $16 \pm 3 b$ & $121 \pm 26 b c$ & $71.0 \pm 24.6$ \\
\hline 50 & $75.0 \pm 10.0$ & $100 \pm 0$ & $16 \pm 4 b$ & $17 \pm 3 \mathrm{ab}$ & $180 \pm 4 \mathrm{a}$ & $82.8 \pm 31.6$ \\
\hline 75 & $70.0 \pm 25.8$ & $100 \pm 0$ & $15 \pm 3 \mathrm{bc}$ & $17 \pm 3 \mathrm{ab}$ & $143 \pm 7 \mathrm{abc}$ & $85.7 \pm 14.7$ \\
\hline 100 & $90.0 \pm 11.5$ & $100 \pm 0$ & $11 \pm 3 c$ & $14 \pm 5 b$ & $110 \pm 17 \mathrm{c}$ & $45.5 \pm 25.2$ \\
\hline
\end{tabular}

${ }^{\mathrm{z}}$ Weights per plant obtained after drying of the root and stalk. ${ }^{\mathrm{y}}$ Different letters in each column indicate means are significantly different $(p<0.05)$ using Tukey-Kramer HSD post-hoc test. nd $=$ no difference.

\subsection{Seedling Emergence}

The ability of two common crops, corn and carrots, to emerge and grow were evaluated in each blend over 14 days. The plants were arranged to insure all plants received adequate daylight, resulting in soil warming to encourage seedling emergence, as shown in Figure 1. The observed temperatures were within published limits that promote germination and emergence [44]. Rainfall was monitored over the time to emergence and the 14 days of growth, however only $1.0 \mathrm{~mL}$ of rain was collected during the carrot trial and $7.5 \mathrm{~mL}$ of rain during the corn trial. This resulted in the carrot trial requiring one external watering of $1 \mathrm{~L}$ to each pot. The under pan watering system supplied the necessary water for the corn when combined with the rain.

Corn emergence was consistent within the various depleted marc blends and the emerged corn had $100 \%$ viability, as shown in Table 2 . The root lengths of the individual plants were significantly reduced by depleted marc; however, the stalk lengths of the $50 \%$ and $75 \%$ blends were statistically similar to the control but the $25 \%$ and $100 \%$ blends reduced it. Although the root length decreased, the root mass per plant was the same as the control, except that $50 \%$ depleted marc was significantly greater, and $100 \%$ depleted marc was significantly less. This suggests that although the roots did not penetrate as deeply, a larger root structure had developed creating a root ball in the $50 \%$ depleted marc. The creation of a root ball could be indicative of compaction and difficulty of the roots to penetrate vertically; however, sufficient nutrients in the sub-surface layer would result in no decrease in growth or yield [45]. The decrease in the root lengths combined with the observed root ball suggest that the soil may have been too loose, and the roots were unable to extract sufficient nutrients [46]. The decrease in corn root and stalk lengths, and weight, in the $100 \%$ depleted marc suggest that some detrimental effects of the marc remained after depletion; this was also evidenced through observations of the plantings as the corn leaf tips showed signs of browning, as shown in Figure 2. The decreased root growth of the $100 \%$ depleted marc combined with the equivalent percent emergence, indicated phytotoxicity, which is supported by the studies of Paradelo et al. [31], who saw a similar effect in barley and rye grass grown in grape marc compost. 


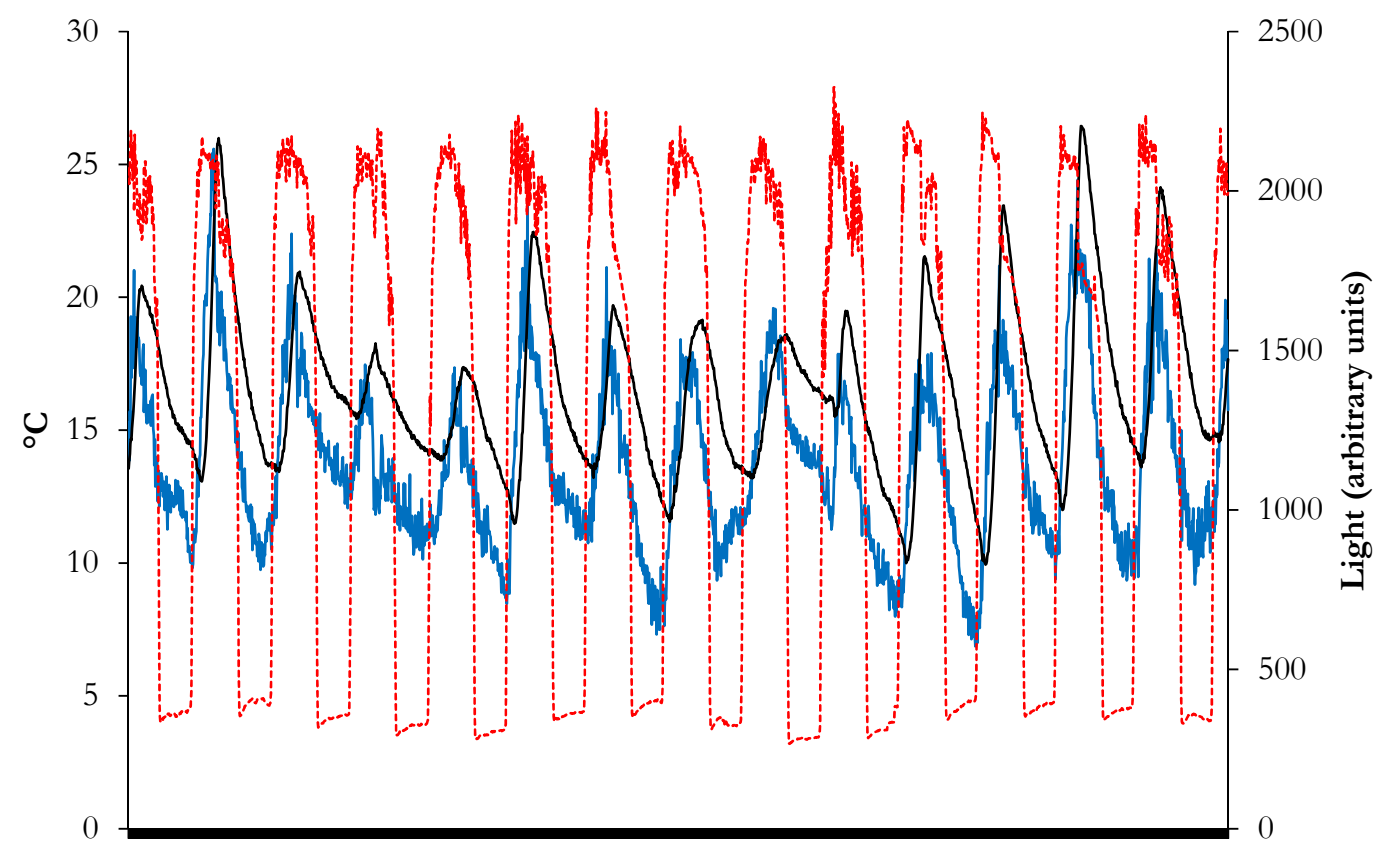

Figure 1. Representative plot of 14 daylight, soil temperature, and air temperature recordings taken during the seedling emergence trials.

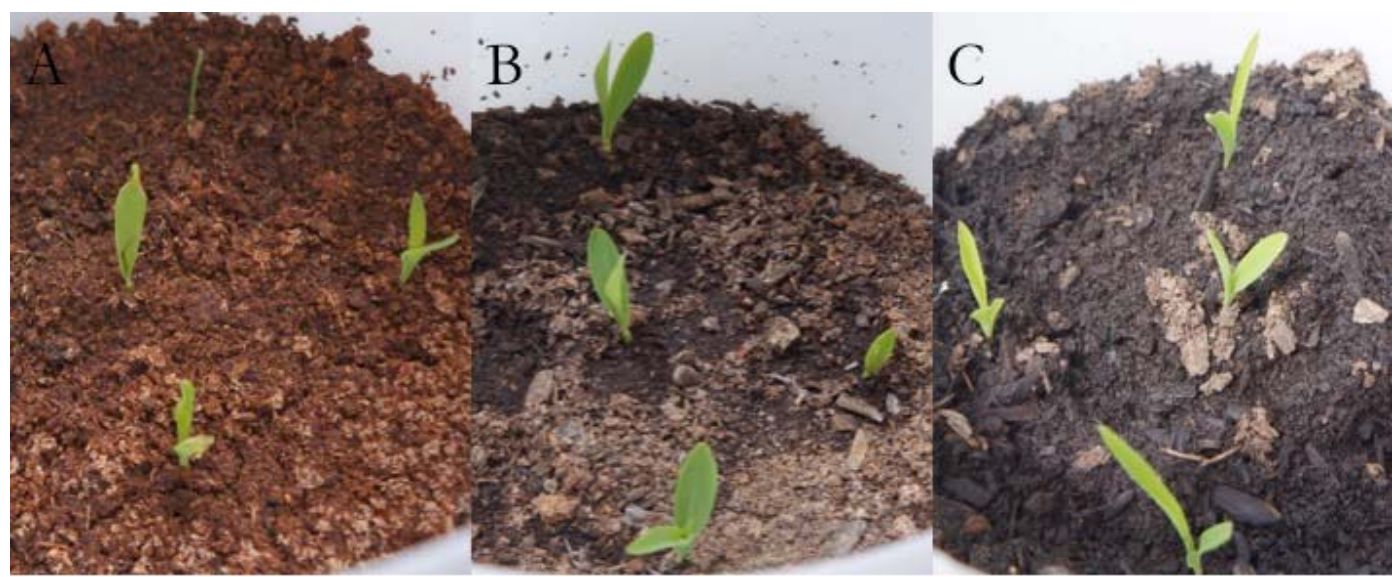

Figure 2. Corn plants at Day 2 post-emergence in (A) 100\% depleted marc, (B) 50:50 depleted marc/compost, and (C) 100\% compost.

Achmon et al. [47] used a 5\% white grape marc (undepleted) soil blend and observed negative effects on the emergence of lettuce seedlings; the current study far exceeds this concentration, but with a depleted marc. The emergence rates in the blends were similar to the control, and all blends had 100\% viability, demonstrating that germination was less affected by phytotoxins [48-50]. The decreased root length and mass do suggest that phytotoxicity arising from the depleted marc was present and sufficient to inhibit growth in the selected corn species when not blended. However, it is difficult to determine whether these effects were due to residual organic acids, phenolic compounds, or other agents remaining in the marc following extraction.

Carrots, like corn, had equivalent emergence and viability to the control. Stalk lengths were also equal; however, the root length was increased in the $25 \%$ and $50 \%$ blends ( 71.5 and $71.9 \mathrm{~cm}$, respectively) and were also the longest. This increased root length also resulted in increased root weight. The $100 \%$ depleted marc was not significantly different from the control for root length and root weight. The root length and weight results also suggest that the marc blends were able to supply nutrients that the 
carrots required for taproot development. El Sebaaly et al. [51] saw similar increases in root length in lettuce with increasing concentrations of composted grape marc. The observed differences in the lettuce were attributed to the improvement in the soil associated with increased nutrients coming from the composted grape marc.

The emergence of greater than $75 \%$ for all depleted marc blends suggests that phytotoxicity did not present a problem for seed germination and seedling emergence. Toxins can also be found in immature compost, which can release acetic acid, phenols, and other organic compounds at levels that can be phytotoxic [52]. Tamet et al. [53] found that carrot seed weight, sowing depth, and seedbed conditions influenced emergence and early growth. They observed a decrease in emergence with as little as a five mm crust, with a dry crust being more suppressive than a moist one. Crust formations from soil drying as a result of environmental conditions combined with variations in sowing depth are most likely the cause of the variable rates of emergence.

\subsection{Nutrient Profiles}

As a result of the emergence trials, the raw, depleted, $50 \%$, and $100 \%$ depleted marc blends were analyzed for nutrient profiles, as shown in Table 3, to understand the differences in these media. The raw marc results show that there were several beneficial elements present, as well as detrimental elements at high concentrations. The depletion process reduced these values, but some remained at detrimental levels. The electrical conductivity, an indicator of salinity, was high not only in the raw marc, but also in the compost. An electrical conductivity of greater than $4 \mathrm{dS} / \mathrm{m}$ is considered a saline soil and detrimental to many crops [54]. Increased salinity values have been linked to plant growth depression through water deficiency and ion imbalances [55]. Phosphorous and potassium are essential for plant development, and salinity can affect their uptake and can precipitate them from excess calcium [56]. However, only compost and raw marc had values indicating that salinity would be an issue. Carrots are sensitive to salinity which could explain the low emergence rates in the pot trials of compost and the $25 \%$ blend $[57,58]$. The salinity levels and $\mathrm{C} / \mathrm{N}$ ratio of the depleted marc in this study was similar to those seen in composted marc by Paradelo et al. [31] and are conducive to plant emergence and growth. However, the high content of carbon in depleted marc could result in an imbalance of the $\mathrm{C} / \mathrm{N}$ ratio in soils that are deficient in nitrogen, thereby resulting in microbial denitrification of the soils exacerbating nitrogen deficiency [59].

Table 3. Nutrient profiles of grape marc and growing media used in the seedling emergence studies.

\begin{tabular}{|c|c|c|c|c|c|}
\hline Analysis & Raw Marc & Depleted Marc & Blend 50:50 & Compost & Accepted Range [21] \\
\hline Electrical Conductivity (dS/m) & $4.9^{\mathrm{z}}$ & 0.6 & 1.8 & 3.7 & $0.5-1.8$ \\
\hline Nitrate (mg/L) & 41 & 2 & 2 & 2 & $20-80$ \\
\hline Phosphorus (mg/L) & 214 & 55 & 13 & 2 & $5-20$ \\
\hline Potassium (mg/L) & 2170 & 218 & 375 & 538 & $20-80$ \\
\hline Sulfur (mg/L) & 31 & 9 & 137 & 439 & \\
\hline Magnesium (mg/L) & 48 & 2 & 12 & 48 & $7-25$ \\
\hline Sodium (mg/L) & 19 & 3 & 51 & 123 & $5-40$ \\
\hline Iron $(\mathrm{mg} / \mathrm{L})$ & 1.0 & 3.4 & 9.5 & 9.9 & $20.0-50.0$ \\
\hline Zinc (mg/L) & 1.2 & 1.0 & 5.7 & 7.8 & $0.3-10.0$ \\
\hline Copper $(\mathrm{mg} / \mathrm{L})$ & 1.0 & 0.3 & 0.3 & 0.3 & $0.4-10$ \\
\hline Boron (mg/L) & 3.2 & 0.6 & 0.2 & 0.2 & $0.1-0.7$ \\
\hline C/N Ratio & 28 & 22 & 22 & 23 & \\
\hline
\end{tabular}

${ }^{\mathrm{z}}$ Values are from analysis of a single sample of each medium. 
The extraction process not only lowered the levels of phytotoxins present, through the extraction of the desired polyphenolic compounds as well as the incidental removal of other compounds, but it also reduced the nutrient concentrations available. Since the raw marc contained excessively high concentrations of certain elements, this reduction is both warranted and beneficial for supporting plant growth. Furthermore, the blending of the depleted marc with compost situated the blended nutrients in the desired "accepted range" [60]. This adjustment from the raw depleted marc allows the soil to be more conducive to plant growth. The nutrient profiles of the depleted marc and marc blends suggest that they would support multiple types of plant growth [61]. Further pot and field trials are required to confirm that soil amendments with depleted marc will support plant growth.

\section{Conclusions}

It was established that a depleted grape marc can support the emergence of seeds and support plant growth. A compost and depleted marc blend of 50:50 was the most effective blend, based on the lack of a significant effect on seedling emergence and viability, and on lack of negative effects on related parameters, except for corn root lengths. Further experiments are necessary to elucidate the cause of the corn root observations. The $50 \%$ blend performed in a manner that would permit its use as a potting material. The nutrients of $50 \%$ blend also indicated that it would promote growth. The high moisture content $(>85 \%)$ of the blends would not only support the germination of seeds but suggests that its use as a soil additive in marginal soils would reduce erosion and runoff.

The risk that phenolic compounds and other phytotoxins may inhibit emergence appears to be mitigated by the depletion process employed as evidenced from the lack of effects on seedling emergence and viability. While some antioxidant components remained, the blending with compost minimized the observed phytotoxic effects. The use of water as the extracting solvent allowed for the depleted marc to be utilized without any further processing.

The valorization of the grape marc through the extraction of the phytochemicals, for applications in other industries, combined with the ability to utilize the depleted marc without composting provides an opportunity for a truly closed-loop process. This would not only address the challenges faced in the disposal of the marc by wineries but would also increase the sustainability of the industry.

Author Contributions: Author contribution is as follows: conceptualization, K.J.O. and P.A.K.; methodology, K.J.O., P.A.K., and B.F.; formal analysis, K.J.O.; investigation, K.J.O. and C.V.; resources, P.A.K.; writing-original draft preparation, K.J.O.; writing-review and editing, B.F., P.A.K., and C.V.; supervision, B.F. and P.A.K.; project administration, K.J.O.; funding acquisition, K.J.O.

Funding: This work was funded through a University of Auckland Postgraduate Research Student Support grant and financial support for KJ Olejar was provided by a New Zealand International Doctoral Research Scholarship. A PhD scholarship for C Vandermeer was provided by the MBIE Biocide Toolbox programme.

Conflicts of Interest: The authors declare no conflict of interest.

\section{References}

1. Muhlack, R.A.; Potumarthi, R.; Jeffery, D.W. Sustainable wineries through waste valorisation: A review of grape marc utilisation for value-added products. Waste Manag. 2018, 72, 99-118. [CrossRef]

2. Arvanitoyannis, I.S.; Varzakas, T.H. Fruit/Fruit juice waste management: Treatment methods and potential uses of treated waste. In Waste Management for the Food Industries; Academic Press: Amsterdam, The Netherlands, 2008; pp. 569-628.

3. Carmona, E.; Moreno, M.T.; Avilés, M.; Ordovás, J. Use of grape marc compost as substrate for vegetable seedlings. Sci. Hortic. 2012, 137, 69-74. [CrossRef]

4. Greenwood, S.L.; Edwards, G.R.; Harrison, R. Supplementing grape marc to cows fed a pasture-based diet as a method to alter nitrogen partitioning and excretion. J. Dairy Sci. 2012, 95, 755-758. [CrossRef] [PubMed]

5. Moate, P.J.; Williams, S.R.O.; Torok, V.A.; Hannah, M.C.; Ribaux, B.E.; Tavendale, M.H.; Eckard, R.J.; Auldist, M.J.; Wales, W.J. Grape marc reduces methane emissions when fed to dairy cows. J. Dairy Sci. 2014, 97, 5073-5087. [CrossRef] [PubMed] 
6. Patel, S.; Shukla, S. Fermentation of food wastes for generation of nutraceuticals and supplements. In Fermented Foods in Health and Disease Prevention; Frias, J., Martinez-Villaluenga, C., Peña, E., Eds.; Academic Press: Boston, MA, USA, 2017; pp. 707-734.

7. Santos, N.W.; Santos, G.T.D.; Silva-Kazama, D.C.; Grande, P.A.; Pintro, P.M.; de Marchi, F.E.; Jobim, C.C.; Petit, H.V. Production, composition and antioxidants in milk of dairy cows fed diets containing soybean oil and grape residue silage. Livest. Sci. 2014, 159, 37-45. [CrossRef]

8. Zalikarenab, L.; Pirmohammadi, R.; Teimuriyansari, A. Chemical composition and digestibility of dried white and red grape pomace for ruminants. J. Anim. Vet. Adv. 2007, 6, 1079-1082.

9. Bustamante, M.A.; Moral, R.; Paredes, C.; Pérez-Espinosa, A.; Moreno-Caselles, J.; Pérez-Murcia, M.D. Agrochemical characterisation of the solid by-products and residues from the winery and distillery industry. Waste Manag. 2008, 28, 372-380. [CrossRef] [PubMed]

10. Gruda, N.S. Increasing sustainability of growing media constituents and stand-alone substrates in soilless culture systems. Agronomy 2019, 9, 298. [CrossRef]

11. Gómez-Brandóón, M.; Lores, M.; Insam, H.; Domínguez, J. Strategies for recycling and valorization of grape marc. Crit. Rev. Biotechnol. 2019, 39, 437-450. [CrossRef]

12. Kritsotakis, I.K.; Kabourakis, E.M. Grape vine waste and giant reed biomass composts as peat and mineral fertilizer substitutes for producing organic tomato transplants. J. Crop. Improv. 2011, 25, 664-679. [CrossRef]

13. Burg, P.; Vítěz, T.; Turan, J.; Burgová, J. Evaluation of grape pomace composting process. ACTA Univ. Agric. Fac Silvicult. 2014, 62, 875-881. [CrossRef]

14. Devesa-Ray, R.; Vecino, X.; Varela-Alende, J.L.; Barral, M.T.; Cruz, J.M.; Moldes, A.B. Valorization of winery waste vs. the costs of not recycling. Waste Manag. 2011, 31, 2327-2335. [CrossRef] [PubMed]

15. Ribéreau-Gayon, P.; Dubourdieu, D.; Donèche, B.; Lonvaud, A. Handbook of Enology; John Wiley \& Sons Ltd.: Chichester, UK, 2001.

16. Garcia-Jares, C.; Vazquez, A.; Lamas, J.P.; Pajaro, M.; Alvarez-Casas, M.; Lores, M. Antioxidant white grape seed phenolics: Pressurized liquid extracts from different varieties. Antioxidants 2015, 4, 737-749. [CrossRef] [PubMed]

17. Giuffrè, A.M. HPLC-DAD detection of changes in phenol content of red berry skins during ripening. Eur. Food Res. Technol. 2013, 237, 555-564. [CrossRef]

18. Niu, S.; Hao, F.; Mo, H.; Jiang, J.; Wang, H.; Liu, C.; Fan, X.; Zhang, Y. Phenol profiles and antioxidant properties of white skinned grapes and their coloured genotypes during growth. Biotechnol. Biotec. Eq. 2017, 31, 58-67. [CrossRef]

19. Kähkönen, M.P.; Hopia, A.I.; Vuorela, H.J.; Rauha, J.-P.; Pihlaja, K.; Kujala, T.S.; Heinonen, M. Antioxidant activity of plant extracts containing phenolic compounds. J. Agric. Food Chem. 1999, 47, 3954-3962. [CrossRef]

20. Garcia-Salas, P.; Morales-Soto, A.; Segura-Carretero, A.; Fernández-Gutiérrez, A. Phenolic-compoundextraction systems for fruit and vegetable samples. Molecules 2010, 15, 8813-8826. [CrossRef]

21. Jelley, R.E.; Herbst-Johnstone, M.; Klaere, S.; Pilkington, L.I.; Grose, C.; Martin, D.; Barker, D.; Fedrizzi, B. Optimization of ecofriendly extraction of bioactive monomeric phenolics and useful flavor precursors from grape waste. ACS Sustain. Chem. Eng. 2016, 4, 5060-5067. [CrossRef]

22. Mojzer, E.B.; Hrnčič, M.K.; Škerget, M.; Željko, K.; Bren, U. Polyphenols: Extraction methods, antioxidative action, bioavailability and anticarcinogenic effects. Molecules 2016, 21, 901. [CrossRef]

23. McDOnnell, G.; Russell, A.D. Antiseptics and disinfectants: Activity, action, and resistance. Clin. Microbiol. Rev. 1999, 12, 147-179. [CrossRef]

24. Man, A.; Gâz, A.Ș.; Mare, A.D.; Berța, L. Effects of low-molecular weight alcohols on bacterial viability. Rev. Română Med. Lab. 2017, 25, 335-343. [CrossRef]

25. Curzons, A.D.; Constable, D.C.; Cunningham, V.L. Solvent selection guide: A guide to the integration of environmental, health and safety criteria into the selection of solvents. Clean. Prod. Proc. 1999, 1, 82-90. [CrossRef]

26. Olejar, K.; Ray, S.; Ricci, A.; Kilmartin, P. Superior antioxidant polymer films created through the incorporation of grape tannins in ethyl cellulose. Cellulose 2014, 21, 4545-4556. [CrossRef]

27. Olejar, K.J.; Ray, S.; Kilmartin, P.A. Enhanced antioxidant activity of polyolefin films integrated with grape tannins. J. Sci. Food Agric. 2016, 96, 2825-2831. [CrossRef] [PubMed]

28. Tapas, A.R.; Sakarkar, D.M.; Kakde, R.B. Flavonoids as nutraceuticals: A review. Trop. J. Pharm. Res. 2008, 7, 1089-1099. [CrossRef] 
29. Marlborough Research Centre. Blenhiem Weather Station. Available online: https://www.mrc.org.nz/ blenheim-weather-station (accessed on 3 August 2009).

30. Olejar, K.J.; Ricci, A.; Swift, S.; Zujovic, Z.; Gordon, K.C.; Fedrizzi, B.; Vesari, A.; Kilmartin, P.A. Characterization of an antioxidant and antimicrobial extract from cool climate, white grape marc. Antioxidants 2019, 8, 232. [CrossRef]

31. Paradelo, R.; Moldes, A.B.; Gonzalez, D.; Barral, M.T. Plant tests for determining the suitability of grape marc composts as components of plant growth media. Waste Manag. Res. 2012, 30, 1059-1065. [CrossRef]

32. Naeth, M.A.; Bailey, A.W.; Chanasyk, D.S.; Pluth, D.J. Water holding capacity of litter and soil organic matter in mixed prairie and fescue grassland ecosystems of Alberta. J. Range Manag. 1991, 44, 13-17. [CrossRef]

33. Topp, G.C.; Parkin, G.W.; Ferre, T.P.A. Chapter 70: Soil Water Content. In Soil Sampling and Methods of Analysis, 2nd ed.; Carter, M.R., Gregorich, E.G., Eds.; CRC Press: Boca Raton, FL, USA, 2008; p. 940.

34. Leelamanie, D.A.L.; Karube, J.; Yoshida, A. Characterizing water repellency indices: Contact angle and water drop penetration time of hydrophobized sand. Soil Sci. Plant. Nutr. 2008, 54, 179-187. [CrossRef]

35. Hamza, M.A.; Anderson, W.K. Soil compaction in cropping systems: A review of the nature, causes and possible solutions. Soil Till Res. 2005, 82, 121-145. [CrossRef]

36. Håkansson, I.; Lipiec, J. A review of the usefulness of relative bulk density values in studies of soil structure and compaction. Soil Till Res. 2000, 53, 71-81. [CrossRef]

37. United States Environmental Protection Agency. OCSPP 850.4230: Early seedling growth toxicity test. In Ecological Effects Test Guidelines; Office of Chemical Safety and Pollution Prevention; US Environmental Protection Agency: Washington, DC, USA, 2012.

38. Ros, M.; Garcia, C.; Hernandez, T. The use of urban organic wastes in the control of erosion in a semiarid Mediterranean soil. Soil Use Manag. 2001, 17, 292-293. [CrossRef]

39. Bucić-Kojić, A.; Planinić, M.; Tomas, S.; Jakobek, L.; Šeruga, M. Influence of solvent and temperature on extraction of phenolic compounds from grape seed, antioxidant activity and colour of extract. Int. J. Food Sci. Technol. 2009, 44, 2394-2401. [CrossRef]

40. Gentili, R.; Ambrosini, R.; Montagnani, C.; Caronni, S.; Citterio, S. Effect of soil pH on the growth, reproductive investment and pollen allergenicity of Ambrosia artemisiifolia L. Front. Plant Sci. 2018, 9, 1335. [CrossRef] [PubMed]

41. Mohammadshirazi, F.; McLaughlin, R.A.; Heitman, J.L.; Brown, V.K. A multi-year study of tillage and amendment effects on compacted soils. J. Environ. Manag. 2017, 203 Pt 1, 533-541. [CrossRef]

42. Ahmad, D. Rate of water absorption by soil clods under confined and unconfined conditions. Malays. J. Soil Sci. 1997, 1, 65-76.

43. An, N.; Tang, C.-S.; Xu, S.-K.; Gong, X.-P.; Shi, B.; Inyang, H.I. Effects of soil characteristics on moisture evaporation. Eng. Geol. 2018, 239, 126-135. [CrossRef]

44. Alessi, J.; Power, J.F. Corn emergence in relation to soil temperature and seedling depth. Agron. J. 1971, 63, 717-719. [CrossRef]

45. Australian Standards. Potting Mixes; AS3743-1989; Standards Australia: Sydney, Australia, 1989.

46. Standards New Zealand. Composts, Soil Conditioners and Mulches; NZS4454:2005; New Zealand Standards: Wellington, New Zealand, 2005.

47. Achmon, Y.; Harrold, D.R.; Claypool, J.T.; Stapleton, J.J.; Vander Gheynst, J.S.; Simmons, C.W. Assessment of tomato and wine processing solid wastes as soil amendments for biosolarization. Waste Manag. 2016, 48, 156-164. [CrossRef]

48. Emino, E.R.; Warman, P.R. Biological assay for compost quality. Compost. Sci. Util. 2004, 12, 342-348. [CrossRef]

49. Ozdener, Y.; Kutbay, H.G. Toxicity of copper, cadmium, nickel, lead and zinc on seed germination and seedling growth in Eruca sativa. Fresen. Environ. Bull. 2009, 18, 26-31.

50. Paradelo, R.; Cendon, Y.; Moldes, A.B.; Barral, M.T. Relationship between heavy metals and phytotoxicity in compost. Ciencia Technol. Alim. 2008, 6, 143-151. [CrossRef]

51. El Sebaaly, Z.; Kfoury, L.; Nabhan, G.; Shaban, N.; Sassine, Y.N. Use of local composted winery waste for lettuce production in Labanon. AGROFOR Int. J. 2017, 2, 99-107.

52. Liebman, D. Integration of soil, crop and weed management in low-external-input farming systems. Weed Res. 2000, 40, 27-47. [CrossRef] 
53. Tamet, V.; Boiffin, J.; Dürr, C.; Souty, N. Emergence and early growth of an epigeal seedling (Daucus carota L.): Influence of soil temperature, sowing depth, soil crusting and seed weight. Soil Till Res. 1996, 40, 25-38. [CrossRef]

54. Munns, R. Genes and salt tolerance: Bringing them together. New Phytologist. 2005, 167, 645-663. [CrossRef]

55. Paul, D. Osmotic stress adaptions in rhizobacteria. J. Basic Microb. 2013, 53, 101-110. [CrossRef]

56. Shrivastava, P.; Kumar, R. Soil salinity: A serious environmental issue and plant growth promoting bacteria as one of the tools for its alleviation. Saudi J. Biol. Sci. 2015, 22, 123-131. [CrossRef]

57. Nagaz, K.; Masmoudi, M.M.; Mechlia, N.B. Impacts of irrigation regimes with saline water on carrot productivity and soil salinity. J. Saudi Soc. Agric. Sci. 2012, 11, 19-27. [CrossRef]

58. Schmidhalter, U.; Oertli, J.J. Germination and seedling growth of carrots under salinity and moisture stress. Plant Soil 1991, 132, 243-251. [CrossRef]

59. Qian, J.H.; Doran, J.W.; Walters, D.T. Maize plant contributions to root zone available carbon and microbial transformations of nitrogen. Soil Biol. Biochem. 1997, 29, 1451-1462. [CrossRef]

60. RJ Hill Laboratories Ltd. 2016. Available online: https://www.hill-laboratories.com (accessed on 10 June 2019).

61. Food and Agriculture Organization of the United Nations. Plant Nutrition for Food Security: A Guide for Integrated Nutrient Management; Food and Agriculture Organization of the United Nations: Rome, Italy, 2006.

(C) 2019 by the authors. Licensee MDPI, Basel, Switzerland. This article is an open access article distributed under the terms and conditions of the Creative Commons Attribution (CC BY) license (http://creativecommons.org/licenses/by/4.0/). 